\title{
Traumatic Isolated Posterior Elbow Dislocation: Pediatric case report
}

\section{Travmatik Izole Posteriyor Dirsek Çıkığı: Çocuk Olgu sunumu}

\section{Gökhan Bülent Sever', Mehmet Cenk Cankuş', Levent Bostancı', Mehmet Dokur²}

1 Sanko Üniversitesi Tıp Fakültesi, Ortopedi Ve Travmatoloji Ana Bilim Dalı, Gaziantep

2 Sanko Üniversitesi Tıp Fakültesi Hastanesi, Acil Servis, Gaziantep, Türkiye

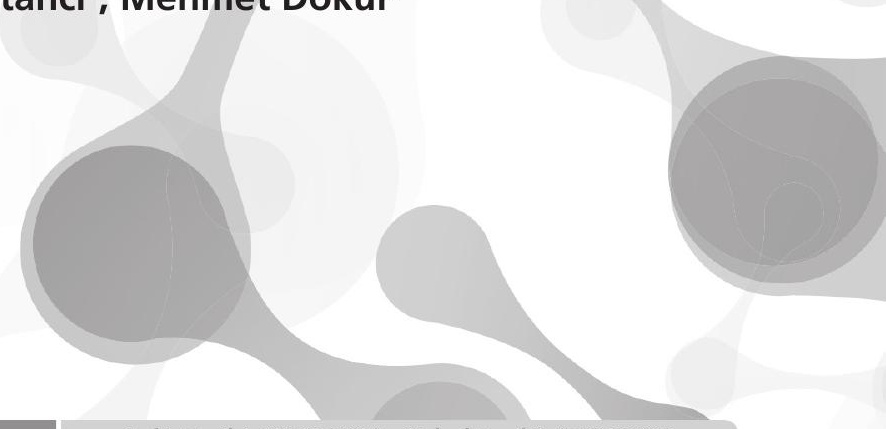

Travmatik izole dirsek çıkıkları erken çocukluk döneminde oldukça nadir görülür. Ancak çocukluk çağında posteriyor dirsek çıkıkları daha sıktır ve genellikle dirsek çevresi kırıkları ile birlikte görülür.

Biz bu çalışmada, 8 yaşındaki bir erkek çocuğunda evde dirsek üzerine düşme sonrasında gelişen ve nadir görülen izole posteriyor dirsek çıkığı olgusunu inceledik. Genel anestezi altında kapalı redüksiyon ve uzun kol ateli uygulanan çocuk hasta için iki haftalık immobilizasyon önerildi. Klinik takipleri sonunda hastanın dirsek hareketlerini tam ve ağrısız olarak yapabildiği gözlendi. Karşılaştırmalı dirsek grafileri çekilmesi tanısal açıdan önemlidir.

Anahtar Kelimeler: travmatik izole dirsek çıkı̆̆ı, çocuk hasta

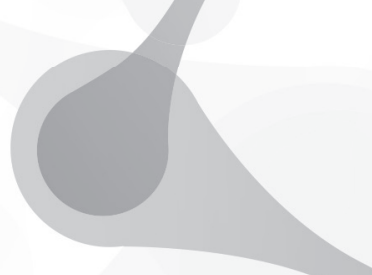

Received : 07.06.2014 Accepted: 27.04.2015

Traumatic isolated elbow dislocations is rare in early childhood. However, posterior dislocation of the elbow is more common in childhood and is often seen with elbow fractures.

In this study, we evaluated a rarely encountered isolated posterior elbow dislocation case developed in a 8-year old boy due to falling on elbow at house. Under general anesthesia, closed reduction and long arm splint was performed and recommended for a two-week immobilisation was recommended for patient. Patients underwent clinical follow-up, it was observed that the elbow can be full and painless. Comparative X-ray of the elbow is diagnostically important.

Keywords: traumatic isolated elbow dislocation, pediatric case 


\section{Introduction}

Isolated elbow dislocations are encountered quite rarely and they are generally related with extra or intra-articular fractures. Traumatic elbow dislocations are rare especially in children under 8 years and its frequency in this age group is around $3-6 \%$ of all elbow injuries ${ }^{1,2}$. When we look at the literature, incidence rates of elbow dislocations together with elbow injuries are reported between $50 \%$ and $75 \%$ in various series of studies ${ }^{3,4}$. In trauma related elbow injuries, rupture of medial epicondyle is most frequent associated injury ${ }^{5}$. In one study, a transverse divergent dislocation in elbow joint together with the rupture of coronoid process developed secondary to elbow trauma in 4-year old girl was informed ${ }^{6}$. Isaac et.al reported a case of isolated posterior elbow dislocation developed in a 18-months old girl who fell on her non-dominant arm². In this study, we reported isolated posterior elbow dislocation case developed in a 8-year old boy due to falling.

\section{Case Report}

Our case, 8-year old boy whose right hand is dominant fell on his right arm strained while playing at home. They applied to our emergency service with complaint of painful and deformed right elbow. Arrival exdamination evaluated as isolated closed right elbow injury, elbow joint of the case was swollen and in approximately 60 degrees flexion, his actions were restricted and painful. Right hand was pink and seemed hot and capillary back-flow was less than 2 seconds. Direct radiographic findings were consistent with dorsal-ulnar total elbow dislocation in right elbow joint and no accompanying fracture was reviewed (Figure 1. A and B).

Informed consent form was taken from father of the child and the patient was taken to operation room within 2 hours. Closed reduction was performed to the case with manipulation under general anaesthesia and then long arm splint was applied for immobilization (Figure 2. A,B and Figure 3.A). Performed joint reduction was checked under scopy and operation was terminated. (Figure 3.B)

The patient was discharged from orthopaedic clinic postoperative day 1 and recalled again for control. First control was performed after 7 days at orthopaedic clinic. It was seen with control plain radiograph that elbow reduction was on- going in a healthy way. The splint was changed and instability control could not be performed.

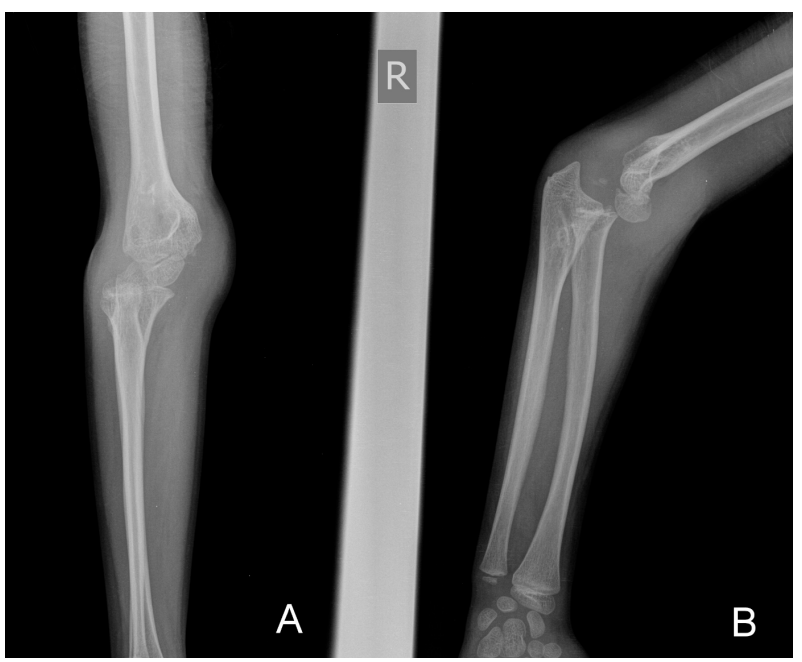

Figure 1. Radiographical images of right postero-lateral elbow dislocation for A-P (A) and lateral (B).
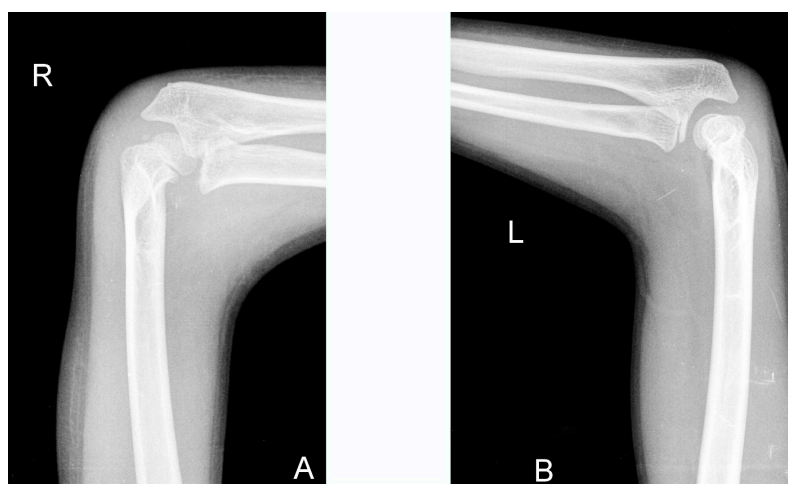

Figure 2. Comparative radiographical lateral images of right elbow joint after closed reduction under general anesthesia and intact left elbow joint ( $A$ and $B$ ).

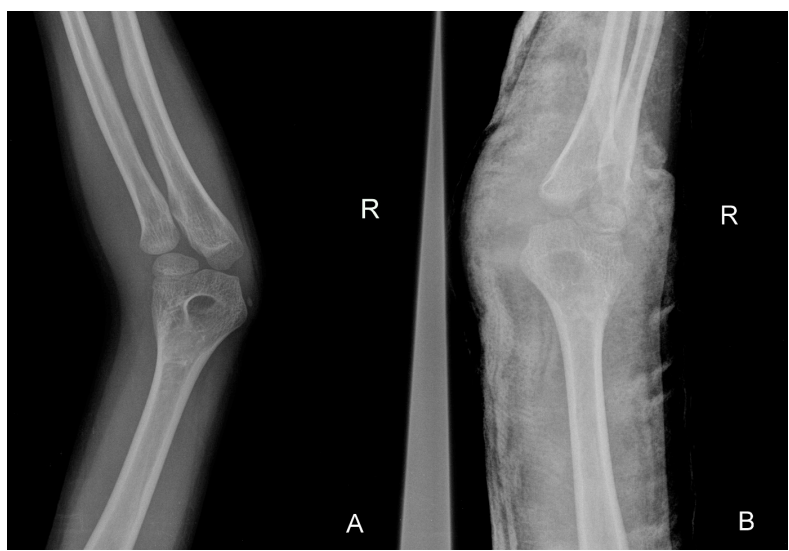

Figure 3. A-P radiographical images of right elbow joint after closed reduction (A) and application of plaster slab (B). 
The patient child was called for the next control after postoperative 14 days, and his long arm splint was taken out. In this case, active mobilization of the case was allowed. After removal of splint, action range was a flexion action between 10-90 degrees with full pronation and supination (Mayo elbow performance scoring was evaluated as 85$)^{8}$. Postoperative day 30, he was able to perform right elbow actions fully and painless, and joint stability was also complete (Mayo elbow performance scoring was evaluated as 100).

\section{Discussion}

Dislocations after trauma are most frequently encountered in shoulder joints, followed by elbow dislocations. Elbow injuries are the most frequent traumatic skeletal injuries after forearm injuries 1.9 . Most of elbow joint injuries are closed injuries. The most common type of elbow joint is posterior type and frequently non-dominant extremity is injured. Common mechanism is falling on strained $\mathrm{arm}^{9,10,12}$. Elbow dislocation mechanism in our case also occurred in the same way. However, development of isolated elbow dislocation upon falling of our case on upper extremite in dominant side is quite striking for our case to the contrary of literature.

Closed reduction under general anaesthesia is generally quite successful in most of isolated elbow dislocations. In general, unreduced dislocations, reductions related with fractures and neurovascular injuries require operation. Active movements following a short mobilization period is recommended and this is in favour of good result $t^{1,7,10,11}$. For our case, we considered that control one week after the reduction and a maximum 2 weeks of immobilization would be better for this age group. Peak age for elbow fractures is 13-14 ages. This age is the period when physis layer starts to close. In early childhood which is immature in terms of skeletal structure, bones are weaker than ligaments and a major trauma applied to elbow will result in bone injury rather than isolated elbow dislocation ${ }^{12,13,14}$. In conclusion, development of isolated elbow dislocation without distal humerus, proximal radius and epiphyseal separation of ulna is less common in young children this is especially encountered quite rarely in children under 5 years. Normal elbow radiographic of opposite side can be useful for comparison?.

\section{Conclusion}

Elbow dislocations are not common in children. This is mostly related with elbow region fractures. Isolated elbow dislocations are even much less frequent in children under 8 years. Considering that this clinical condition is seen rarely, radiographic image of cases with isolated dislocations should be reviewed with great care in terms of trauma related avulsion or fractures. If there is any doubt, comparison with elbow graph of intact or healthy side can be useful for distinguishing such as that injuries.

\section{Conflict of Interests}

The authors declare that they have no conflict of interests.

\section{Consent status}

Parents of the pediatric patient, the information relating to this child were allowed to be used in a scientific study. 
1. Ring $D$, Waters PM. Management of fractures and dislocations of the elbow in children. Acta Orthop Belg $1996 ; 62$ Suppl 1 : 58-65.

2. Wilkins KE. Fractures and dislocations of the elbow region. In : Rockwood CA Jr, Wilkins KE, King RE (eds). Fractures in Children. Vol. 3. Lippincott-Raven, Philadelphia, 1996, p 680.

3. Borris LC, Lassen MR, Christensen CS. Elbow dislocation in children and adults. A long term follow-up of conservatively treated patients. Acta Orthop Scand $1987 ; 58$ : 649-51.

4. Rasool MN. Dislocations of the elbow in children. J Bone Joint Surg 2004 ; 86-B : 1050-8.

5. Fowles JV, Slimane N, Kassab MT. Elbow dislocation with avulsion of the medial humeral epicondyle. J Bone Joint Surg $1990 ; 72-B$ : 102-4.

6. Carey RPL.Simultaneous dislocation of the elbow and proximal radio-ulnar joint. J Bone Joint Surg 1984; 66-B: 254-6.

7. Isaac SM,Danial I,Modi A. Isolated posterior elbow dislocation in a one-year-old child :A case report. Acta Orthop. Belg., 2009; 75(1): 133-5.

8. An KN, Chao EY. Functional evaluation of the elbow. In:Morrey BF, editor. The elbow and its disorders. 2nd ed. Philadelphia: W.B. Saunders; 1993. p. 85-97.

9. Royle SG. Posterior dislocation of the elbow. Clin Orthop $1991 ; 269: 201-4$.

10. Grimer RJ, Brooks S. Brachial artery damage accompanying closed posterior dislocation of the elbow. J Bone Joint Surg 1985 ; 67-B : 378-81.

11. Durakbaşa O,Küçükyazııı Ö,Tuygun $H$,Okan N,Görgeç M. Surgical treatment of elbow fracture-dislocations seen in children and adolescents. Acta Orthop Traumatol Turc 2003;37(4):304-8.

12. Altuntas $A O$, Balakumar J, Howells RJ et al. Posterior divergent dislocation of the elbow in children and adolescents: a report of three cases and review of the literature.J Pediatr Orthop $2005 ; 25$ : 317-21.

13. Hendrikson B. Supra-condylar fractures of the humerus in children. Acta Chir Scand 1966 ; Suppl 369.

14. Lipscomb PR, Burleson RJ. Vascular and neural complications in supra-condylar fractures of the humerus in children. J Bone Joint Surg 1955 ; 37-A : 487-92. 